\title{
Functionalization of Silver/Titanium Dioxide Composites in Chitosan-based Coatings and their Egg Preservation Performances
}

\author{
Xuandong Chen ${ }^{1,2}$, Winfred Zhong Wang ${ }^{3}$, Yuanhao Wang ${ }^{\star}{ }^{, 4,5}$, Shifeng Wang ${ }^{*}, 6,7$ \\ ${ }^{1}$ College of Civil and Architecture Engineering, Guilin University of Technology ${ }^{2}$ Guangxi Key Laboratory of New Energy and Building Energy \\ Saving ${ }^{3}$ Saint James School ${ }^{4}$ Guangxi Beibu Gulf Engineering Research Center for Green Marine Materia ${ }^{5}$ Guangxi Engineering Research \\ Center for Solid Waste Resources Development and Application, Guilin University of Technology ${ }^{6}$ Department of Physics, College of Science, Tibet \\ University ${ }^{7}$ Institute of Oxygen Supply, Tibet University \\ *These authors contributed equally
}

\section{Corresponding Authors}

Yuanhao Wang

yuanhaowang@ppsuc-edu.cn

Shifeng Wang

wsf@utibet.edu.cn

\section{Citation}

Chen, X., Wang, W.Z., Wang, Y., Wang, S. Functionalization of Silver/ Titanium Dioxide Composites in Chitosan-based Coatings and their Egg Preservation Performances. J. Vis. Exp. (173), e61850, doi:10.3791/61850 (2021).

\section{Date Published}

July 2, 2021

DOI

$10.3791 / 61850$

URL

jove.com/video/61850

\section{Abstract}

Eggs are an excellent source of proteins, minerals, and vitamins, which have been popularly consumed in daily diet all over the world. The micro-pores and micro-cracks on the eggshells, however, lead to the loss of moisture and the escape of $\mathrm{CO}_{2}$, resulting in the acceleration of egg deterioration and economic loss. To enhance the stability and sterilizability of the existing chitosan-based coating materials and to develop novel multifunctional nano-composites for anti-bacterial and egg preservation, silver/titanium dioxide $\left(\mathrm{Ag} / \mathrm{TiO}_{2}\right)$ composites are synthesized and applied to modify chitosan for the extension of the egg shelf life. Electron microscope (SEM) images are used to analyze the structure and morphology of composite particles and the morphology of coated eggshells. The preservation performances of composite coatings are evaluated by various parameters: weight loss, Haugh unit, albumen $\mathrm{pH}$ and eggshell morphologies of the samples. Adoption of $\mathrm{Ag} / \mathrm{TiO}_{2}$ composites contributes to a synergistic effect to chitosan, which could prolong the preservation period further. The performances of chitosan coating, however, are presently limited by the existing particle species and concentration, which requires optimization in future studies. Methods in this study examine novel coating materials, which could be created by adding specific nanoparticles into the coating precursor, to achieve the combinative effects of the nanoparticle and the precursor, as well as to prepare novel multifunctional coatings in the field of food preservation. 
As excellent and popular sources of protein, inorganic salt and vitamins, eggs are popular suppliers for human nutrition, which are being produced and consumed worldwide at a large scale ${ }^{1,2}$. Although eggshells are natural protective barriers, they are too fragile to retain their integrity during egg transportation and storage. The gas exchange and microbial penetration between the egg albumen and the environment, which can happen easily through tiny pores on the eggshells, would lead to $\mathrm{CO}_{2}$ loss as well as the deterioration of egg quality ${ }^{3,4}$. Furthermore, tiny cracks on the eggshells would increase the risk of microbial contamination. Therefore, effective egg preservation methods must be urgently developed for economic benefit and human health.

At present, there are two kinds of routes for egg preservation. The first way is to deactivate the microorganisms on the eggshells $5,6,7,8$. The deactivation process extends the egg preservation period by clearing the eggshell surface away from the erosion of environmental microorganisms and moisture. On the other hand, coating the tiny pores and cracks on the eggshell with specific functional materials could also serve as an excellent method to prevent the loss of water vapor and $\mathrm{CO}_{2}$ from the egg albumen, as well as to protect the eggshell from microorganism destruction. As they are simple, effective and energy-saving, coatings are attracting increasing attention for egg preservation. The primary principles that suitable coating materials should meet are chemical stability, effective permeability, wide availability and reliable safety. The most widely studied coating materials are oil ${ }^{9,10}$, proteins $^{11}$, biopolymers ${ }^{3}$, and chitosan ${ }^{12}$.

Chitosan has been regarded as a popular coating material because of its excellent properties of film formation, antibacterial activity, and safety ${ }^{13}$. The egg physicochemical changes and microbial contamination have been proven to be protected by a chitosan coating, which has served as an efficient way for egg preservation. However, as a hydrophilic polymer with poor water vapor barrier and moisture adsorption, chitosan is unstable in a high humidity environment, limiting the preservation effects and reducing the shelf life of eggs to a certain degree.

To overcome this problem and promote the chitosan preservation performance, specific nanoparticles have been used as an adulterant in chitosan-based coatings. Thereinto, as a nano filler with antibacterial character ${ }^{14}$, nano silver (Ag) has been doped to chitosan. The addition of Ag could not only enhance the barrier property of chitosan film, but also enhance its antibacterial effect, which has been proven to improve the preservation effect of the coating. The easy aggregation and simple structure of Ag particles, however, may decrease the stability and durability of the chitosan film, which have been verified to be improved by depositing specific nanoparticles. Titanium dioxide $\left(\mathrm{TiO}_{2}\right)$ is a typical metal oxide compound with excellent properties such as chemical stability, low toxicity as well as reasonable costs. These functional properties endow $\mathrm{TiO}_{2}$ great potential in many research fields ${ }^{15}$. For example, $\mathrm{TiO}_{2}$ particles could serve as additives in medical devices and biomaterials due to their adhesiveness and bactericidal activities. The actual application of $\mathrm{TiO}_{2}$ particles, however, is largely limited by their unstable thermodynamics and agglomerate trends. Therefore, doping specific functional materials into $\mathrm{TiO}_{2}$ has been proposed to achieve the combinative effect of antibacterial activity, improved dispersibility and thermostability.

In this study, antibacterial $\mathrm{Ag} / \mathrm{TiO}_{2}$ composites are synthesized and applied into a chitosan coating for egg preservation. SEM images are used to analyze the structure 
and morphology of the $\mathrm{Ag} / \mathrm{TiO}_{2}$ particles and the eggshells. The preservation performance of the coating is evaluated and compared by weight loss, Haugh unit, albumen $\mathrm{pH}$ and eggshell morphologies. This study demonstrates the possibility and potential of nano composite blended chitosan coatings in food preservation.

\section{Protocol}

\section{Synthesis of nano $\mathrm{Ag} / \mathrm{TiO}_{2}$ composites}

1. To prepare the nano-silver sol, combine $100 \mathrm{~mL}$ of $\mathrm{AgNO}_{3}$ solution, $100 \mathrm{~mL}$ of protective agent and $50 \mathrm{~mL}$ of $\mathrm{NaBH}_{4}$ into a $500 \mathrm{~mL}$ breaker.

1. Mix acetic acid and methanoic acid (analytical grade) at the volume ratio of $1: 1$ to obtain 100 $\mathrm{mL}$ of complex acid solution as the precursor for the protective agent. Dilute the acid solution with deionized water $(18 \mathrm{M} \Omega \cdot \mathrm{cm})$ to $500 \mathrm{~mL}$ as the protective agent.

2. Add $\mathrm{AgNO}_{3}$ solution $(0.3 \mathrm{~mol} / \mathrm{L})$ into the resultant protective agent under vigorous stirring, until $\mathrm{AgNO}_{3}$ solutes are evenly dispersed in the protective solution. Add $0.4 \mathrm{~g}$ of $\mathrm{NaBH}_{4}$ to obtain the welldispersed Ag sol after reacting the mixture for $1 \mathrm{~h}$ at room temperature.

CAUTION: The particle size of nano-silver could be adjusted by the concentration of protective agent and the stirring rate in step 1.1.2.

2. Combine $\mathrm{Ag}$ into tetrabutyl titanate (TBOT)-ethanol solution under stirring and then add $80 \mathrm{~mL}$ of acid catalyst dropwise.

1. Combine $500 \mu \mathrm{L}$ of benzenesulfonic acid (BA) and glacial acetic acid (AA) to obtain the mixed solution
(BA and AA at the volume ratio of 1:2). Dilute the solution into $100 \mathrm{~mL}$ of deionized water $(18 \mathrm{M} \Omega \cdot \mathrm{cm})$ to prepare the acid catalyst.

2. Add the resultant $\mathrm{Ag}$ sol into the pre-dispersed tetrabutyl titanate (TBOT)-ethanol solution ( 2.5 of TBOT in $100 \mathrm{~mL}$ ethanol solution) and stir for $1 \mathrm{~h}$ to obtain the mixed sol. After, add the sol dropwise into $80 \mathrm{~mL}$ of acid catalyst, and stir for $4 \mathrm{~h}$ at $70^{\circ} \mathrm{C}$.

3. Continuously stir the mixture for $48 \mathrm{~h}$ at room temperature to produce the final $\mathrm{Ag} / \mathrm{TiO}_{2}$ composite. CATION: Vigorous stirring may cause splashing of solution drops. Use protective devices to ensure safety, such as a protective oral-nasal mask, a lab gown, and gloves. There is no strict standard for the rotation speed in the abovementioned procedures.

\section{Preparation of chitosan coating}

1. Dissolve chitosan in $1 \%$ (vol) acetic acid and stir for 24 $\mathrm{h}$ at $25{ }^{\circ} \mathrm{C}$ to prepare the coating solution (make sure the chitosan concentration is $0.5 \%$ (wt) in the resultant solution.

2. Add $\mathrm{Ag} / \mathrm{TiO}_{2}$ particles into the suspension separately $\left(0,0.5,1\right.$, and $1.5 \mathrm{~g}$ of $\mathrm{Ag} / \mathrm{TiO}_{2}$ into $50 \mathrm{~g}$ of chitosan solution, respectively), to obtain $0 \%, 1 \%, 2 \%$ and $3 \%$ (wt) $\mathrm{Ag} / \mathrm{TiO}_{2}$-chitosan solutions, denoted as $\mathrm{Ag} / \mathrm{TiO}_{2}-$ $\mathrm{CS} 0, \mathrm{Ag} / \mathrm{TiO}_{2}-\mathrm{CS} 1, \mathrm{Ag} / \mathrm{TiO}_{2}-\mathrm{CS} 2$ and $\mathrm{Ag} / \mathrm{TiO}_{2}-\mathrm{CS} 3$, respectively.

CAUTION: There is no strict standard for the rotation speed in the abovementioned procedures. 


\section{Scanning electron microscopy (SEM) observation}

1. Cut the experimental eggshell into pieces (square dimensions of about 2-3 mm).

2. Immobilize the eggshell pieces on a metal stub with a conductive adhesive (i.e., double-sided carbon conductive tape or other similar materials). Use gloves during the sample preparation to avoid any contamination of the sample from hands. Mark the sample (e.g., with an L-shaped scratch using a diamond pen cutter).

3. Alternatively, apply a sputtered coating with conductive material ( $\sim 10 \mathrm{~nm}$ thick) to prevent charging effects.

4. Acquire at least three high-resolution SEM micrographs (ideally, a minimum of five) from a top view of the sample. Ensure that each image displays an area of at least 25 $\mu \mathrm{m} \times 25 \mu \mathrm{m}$, with a resolution ratio of $20 \mu \mathrm{m}$. Avoid taking images from surface regions with macroscopic surface defects.

5. Use the following SEM parameters: operating voltage of $30 \mathrm{kV}$. The resolution of the second electron image can reach $2 \mathrm{~nm}$ by using a field emission electron gun in a high-grade scanning electron microscope (the ion beam current density is about $10^{5} \mathrm{~A} / \mathrm{cm}^{2}$ ).

6. Note the exact position of each picture with a respect to the L-shaped marker.

\section{Egg preservation experiments}

NOTE: The freshly laid eggs are chicken eggs provided by a local farm in Shenzhen, China.
1. Screen experimental eggs by excluding eggs with cracks, macula or sands on their surfaces to ensure a propitious egg preservation experimental process.

2. Divide the freshly laid eggs into five groups with 30 eggs in each group. Design the four coated groups, which are coated by the chitosan, $\mathrm{Ag} / \mathrm{TiO} 2$-chitosan doped with $0 \%$, $1 \%, 2 \%$ and $3 \%$ (wt) as $\mathrm{Ag} / \mathrm{TiO}_{2}-\mathrm{CS} 0, \mathrm{Ag} / \mathrm{TiO}_{2}-\mathrm{CS} 1, \mathrm{Ag} /$ $\mathrm{TiO}_{2}-\mathrm{CS} 2$ and $\mathrm{Ag} / \mathrm{TiO}_{2}-\mathrm{CS} 3$, respectively.

3. Carry out the coating process to immerse eggs in different coating solutions for $5 \mathrm{~min}$ and dry under ambient condition for $24 \mathrm{~h}$. Set the water washed eggs (WE) as a control experiment. After the abovementioned treatments, store the treated eggs at $25^{\circ} \mathrm{C}$. Take the five marked eggs to measure the weight loss, Haugh unit, albumen $\mathrm{pH}$ and eggshell morphologies to evaluate and compare the preservation performance.

1. Obtain the weight loss (\%) of the egg by calculating the weight difference in percentage of the egg compared to the first day. Measure the weight of eggs in each group every 5 days.

2. Calculate the Haugh unit to relate the egg weight with the thick of albumen (Equation 1) ${ }^{12}$.

$H U=100 \log \left(H-1.7 W^{0.37}+7.6\right)(1)$

where $H$ represents the albumen height $(\mathrm{mm})$ and $W$ represents the egg weight $(\mathrm{g})$.

1. According to the value of Haugh unit, classify the eggs to $A A, A$ and $B$ grade when the Haugh unit of an egg is above 72 , between $71-60$ and below 60, respectively (the United States Standards for Quality of Individual Shell Eggs).

3. Separate the albumen from the yolk and use a digital $\mathrm{pH}$ meter to measure the $\mathrm{pH}$ values of the albumen. 
4. Observe the morphologies of the surfaces of eggshells using a scanning electron microscope after platinum sputtering of the samples.

CATION: The eggshells are brittle substances that cannot stand for violent impacts. Therefore, be careful to avoid any damage to the eggshells.
Moreover, procedures in step 4.3.4 are the same as step 3.

\section{Representative Results}

The particle size of the $\mathrm{Ag} / \mathrm{TiO}_{2}$ composites ranges from $100-300 \mathrm{~nm}$, which is affected by the synthesis conditions (Figure 1).

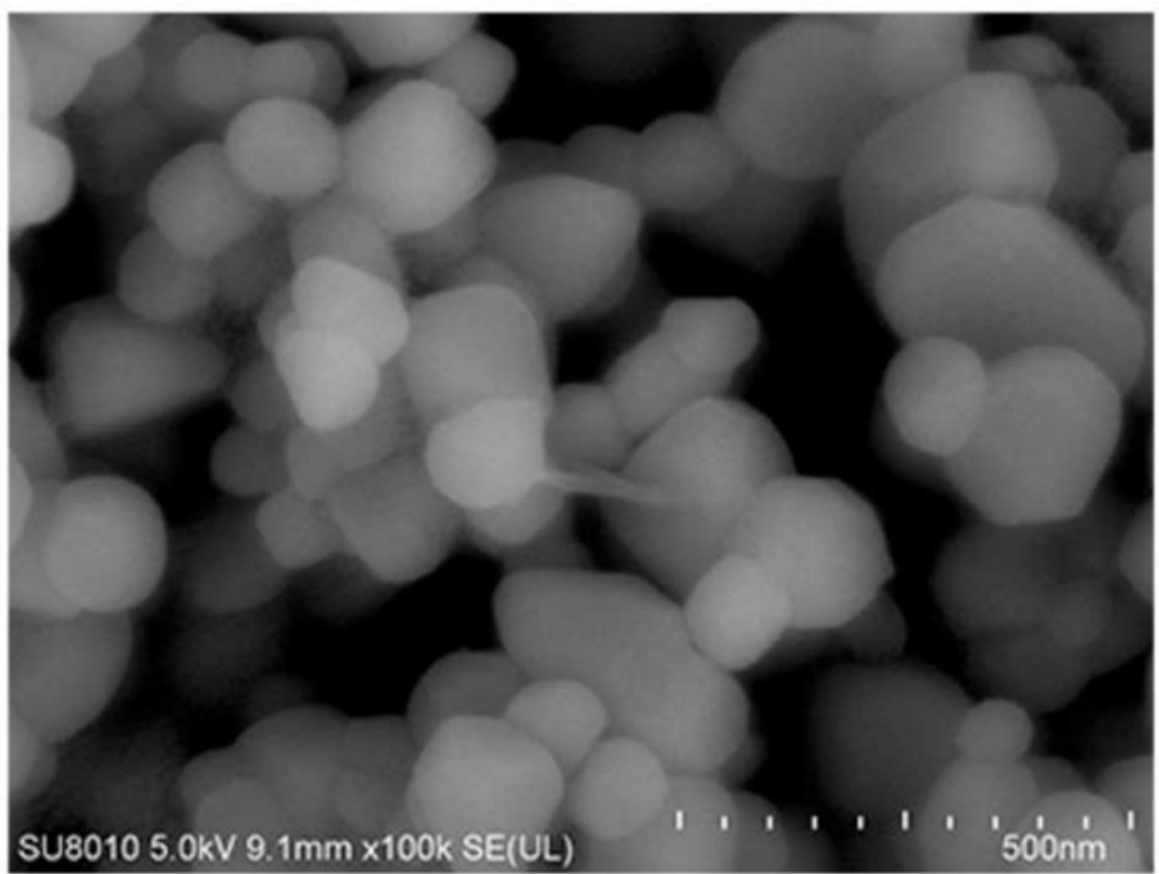

Figure 1: SEM images of $\mathbf{A g} / \mathrm{TiO}_{2}$ composite particles at different resolution ratios $(\mathbf{5 0 0} \mathbf{n m})$. Please click here to view a larger version of this figure.

The weight losses of different egg samples during storage are shown in Table 1. Continuously increased weight loss is due to the escape of albumen $\mathrm{CO}_{2}$ and water vapor through the pores on the eggshells, which leads to the deterioration of egg quality. The weight losses of WE eggs are much higher than for other groups, indicating the protective capacity of chitosan-based coatings for egg quality. After coating by chitosan, the cracks on the eggshell are visibly decreased, which limits the loss of $\mathrm{CO}_{2}$ and water vapor.

\begin{tabular}{|c|c|c|c|c|c|}
\hline \multirow{2}{*}{$\begin{array}{c}\text { Storage } \\
\text { time (day) }\end{array}$} & \multicolumn{5}{|c|}{ Weight loss (wt\%) } \\
\cline { 2 - 6 } & WE & $\mathrm{Ag} / \mathrm{TiO} 2-\mathrm{CSO}$ & $\mathrm{Ag} / \mathrm{TiO} 2-\mathrm{CS} 1$ & $\mathrm{Ag} / \mathrm{TiO} 2-\mathrm{CS} 2$ & $\mathrm{Ag} / \mathrm{TiO} 2-\mathrm{CS} 3$ \\
\hline
\end{tabular}




\begin{tabular}{|c|c|c|c|c|c|}
\hline 6 & $0.78 \pm 0.09 \mathrm{c}$ & $0.69 \pm 0.09 \mathrm{c}$ & $0.53 \pm 0.12 \mathrm{a}$ & $0.49 \pm 0.21 \mathrm{a}, \mathrm{b}$ & $0.48 \pm 0.06 \mathrm{a}$ \\
\hline 11 & $1.85 \pm 0.13 \mathrm{~b}$ & $1.54 \pm 0.18 \mathrm{c}$ & $1.34 \pm 0.15 \mathrm{a}$ & $1.28 \pm 0.13 \mathrm{a}, \mathrm{b}$ & $1.26 \pm 0.21 \mathrm{a}$ \\
\hline 16 & $2.53 \pm 0.21 \mathrm{~b}$ & $2.34 \pm 0.27 \mathrm{c}$ & $1.95 \pm 0.21 \mathrm{~b}$ & $1.93 \pm 0.35 \mathrm{a}$ & $1.89 \pm 0.38 \mathrm{a}$ \\
\hline 21 & $4.01 \pm 0.25 \mathrm{c}$ & $3.63 \pm 0.32 \mathrm{~b}$ & $3.21 \pm 0.09 \mathrm{~b}$ & $3.18 \pm 0.22 \mathrm{a}$ & $3.09 \pm 0.16 \mathrm{a}$ \\
\hline 26 & $4.86 \pm 0.34 \mathrm{~b}$ & $4.18 \pm 0.25 \mathrm{~b}$ & $4.09 \pm 0.39 \mathrm{~b}$ & $4.05 \pm 0.29 \mathrm{a}$ & $3.98 \pm 0.21 \mathrm{a}, \mathrm{b}$ \\
\hline 31 & $5.62 \pm 0.41 \mathrm{a}$ & $5.01 \pm 0.51 \mathrm{~b}$ & $4.76 \pm 0.48 \mathrm{a}$ & $4.69 \pm 0.17 \mathrm{a}$ & $4.58 \pm 0.35 \mathrm{a}$ \\
\hline
\end{tabular}

In the same row with different superscriped letters are significantly different.

Table 1: The variation of weight loss of different eggs during storage time.

Moreover, chitosan coatings doped with $\mathrm{Ag} / \mathrm{TiO}_{2}$ particles are more effective at sealing the pores and forming dense layers, leading to considerably inhibited weight loss. The greater the dosage of the $\mathrm{Ag} / \mathrm{TiO}_{2}$ particles, the stronger the effect of the corresponding coating to reduce $\mathrm{CO}_{2}$ and vapor loss (Figure

2).

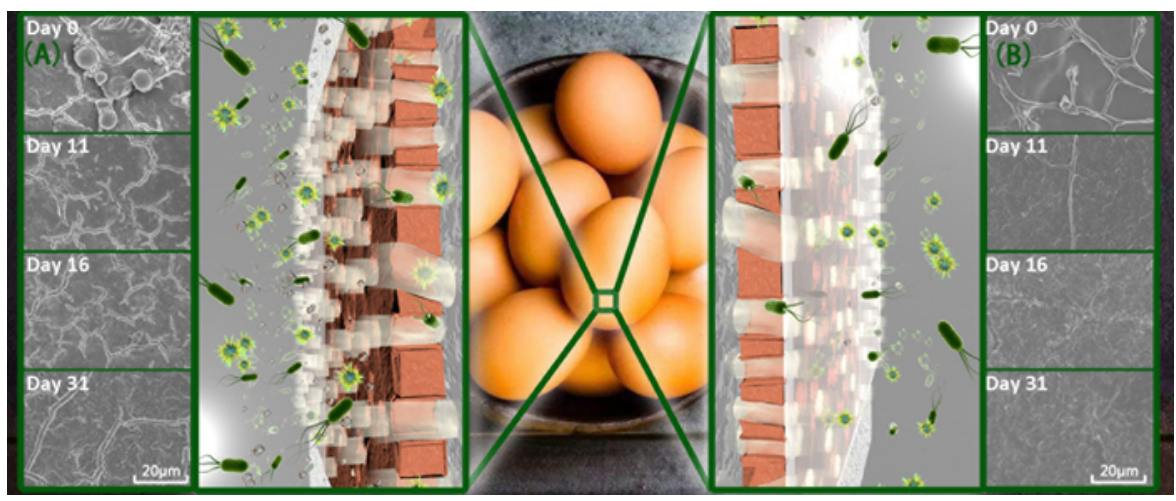

Figure 2: SEM images of the raw eggshell surfaces and chitosan treated eggshell surfaces at day $0,11,16$ and

31. (A) the raw eggshell surfaces; (B) chitosan treated eggshell surfaces. Please click here to view a larger version of this figure.

The Haugh unit is calculated by the age-related changes of the white proteins, reflecting the albumen thinning variation, which is closely related to the protein proteolysis and the albumin $\mathrm{pH}$. The more rapid decrease and invariably lower values of the Haugh unit in the WE group than the chitosan coating groups indicate the effective protective capacity of chitosan. Eggs in chitosan treated groups maintain the superior grade $\mathrm{A}$ for 26 days, while the WE group degrades to grade $\mathrm{B}$ after day 6 . The values of Haugh unit in $\mathrm{Ag} / \mathrm{TiO}_{2}-$ CS1 are always the highest among all the treated groups, 
indicating that: (i) the addition of $\mathrm{Ag} / \mathrm{TiO} 2$ particles contributes to a synergistic effect with chitosan, which are more effective for the coating stabilization and bacterial control; while (ii) excess $\mathrm{Ag} / \mathrm{TiO}_{2}$ particles would destroy the layered structure of chitosan coating, leading to a poorer preservation capacity.
According to the results in Table 2, chitosan doped with 1\% (wt) $\mathrm{Ag} / \mathrm{TiO}_{2}$ particles exhibits the best performance to slow the deterioration of albumen proteins, thus extending the shelf life by up to 30 days.

\begin{tabular}{|c|c|c|c|c|c|}
\hline \multirow{2}{*}{ Storage time (day) } & \multicolumn{5}{|c|}{ Haugh Unit } \\
\cline { 2 - 6 } & $\mathrm{WE}$ & $\mathrm{Ag} / \mathrm{TiO} 2-\mathrm{CS} 0$ & $\mathrm{Ag} / \mathrm{TiO} 2-\mathrm{CS} 1$ & $\mathrm{Ag} / \mathrm{TiO} 2-\mathrm{CS} 2$ & $\mathrm{Ag} / \mathrm{TiO} 2-\mathrm{CS} 3$ \\
\hline 6 & $73.23 \pm 0.68 \mathrm{c}$ & $80.32 \pm 0.59 \mathrm{~b}$ & $83.34 \pm 0.12 \mathrm{a}, \mathrm{b}$ & $81.60 \pm 1.41 \mathrm{a}$ & $77.06 \pm 0.35 \mathrm{a}$ \\
\hline 11 & $69.86 \pm 3.25 \mathrm{c}$ & $75.64 \pm 1.27 \mathrm{~b}$ & $77.18 \pm 2.45 \mathrm{a}, \mathrm{b}$ & $76.05 \pm 3.13 \mathrm{a}, \mathrm{b}$ & $74.32 \pm 1.41 \mathrm{a}$ \\
\hline 16 & $67.31 \pm 2.43 \mathrm{~b}$ & $73.88 \pm 2.06 \mathrm{~b}$ & $75.36 \pm 1.34 \mathrm{a}$ & $75.61 \pm 2.15 \mathrm{a}$ & $71.53 \pm 2.18 \mathrm{a}$ \\
\hline 21 & $62.93 \pm 5.32 \mathrm{c}$ & $71.06 \pm 3.88 \mathrm{c}$ & $73.20 \pm 3.09 \mathrm{a}$ & $72.94 \pm 3.52 \mathrm{a}$ & $69.35 \pm 1.34 \mathrm{a}, \mathrm{b}$ \\
\hline 26 & $58.55 \pm 2.89 \mathrm{~b}$ & $69.85 \pm 1.53 \mathrm{c}$ & $71.85 \pm 2.39 \mathrm{a}$ & $70.34 \pm 4.19 \mathrm{a}, \mathrm{b}$ & $66.21 \pm 2.10 \mathrm{a}$ \\
\hline 31 & $55.24 \pm 3.04 \mathrm{a}$ & $65.26 \pm 0.51 \mathrm{a}$ & $69.31 \pm 3.18 \mathrm{a}$ & $68.96 \pm 1.17 \mathrm{a}$ & $62.64 \pm 4.03 \mathrm{a}$ \\
\hline
\end{tabular}

In the same row with different superscripted letters are significantly different

Table 2: The variation of Haugh unit of different eggs during storage time.

The variation of albumen $\mathrm{pH}$ is caused by $\mathrm{CO}_{2}$ evacuation, leading to a slow increase of $\mathrm{pH}$ values with storage time. The albumen $\mathrm{pH}$ of WE eggs increases sharply within 10 days, and reaches as high as 9.5 at day 30 . The degradation of proteins into fat and peptone leads to a $\mathrm{pH}$ decrease. After being protected by a chitosan coating, the albumen $\mathrm{pH}$ present similar trends within 20 days, which are stabilized at around $\mathrm{pH} 8.0-8.2$. After day 20 , the $\mathrm{pH}$ values of $\mathrm{Ag} /$
$\mathrm{TiO}_{2}-\mathrm{CSO}$ and $\mathrm{Ag} / \mathrm{TiO}_{2}-\mathrm{CS} 1$ show slight fluctuation at around $\mathrm{pH} 8.2$ and stabilize between $\mathrm{pH}$ 7.5-8.0 for $\mathrm{Ag} / \mathrm{TiO}_{2}-\mathrm{CS} 2$ and $\mathrm{Ag} / \mathrm{TiO}_{2}-\mathrm{CS} 3$. The relative stable albumen $\mathrm{pH}$ of treated groups compared with the WE group illustrates the effective reduction of $\mathrm{CO}_{2}$ loss in albumen (Figure 3). The addition of $\mathrm{Ag} / \mathrm{TiO}_{2}$ particle promotes the stability of chitosan, which could maintain good stability until 31 days (Figure 4). 


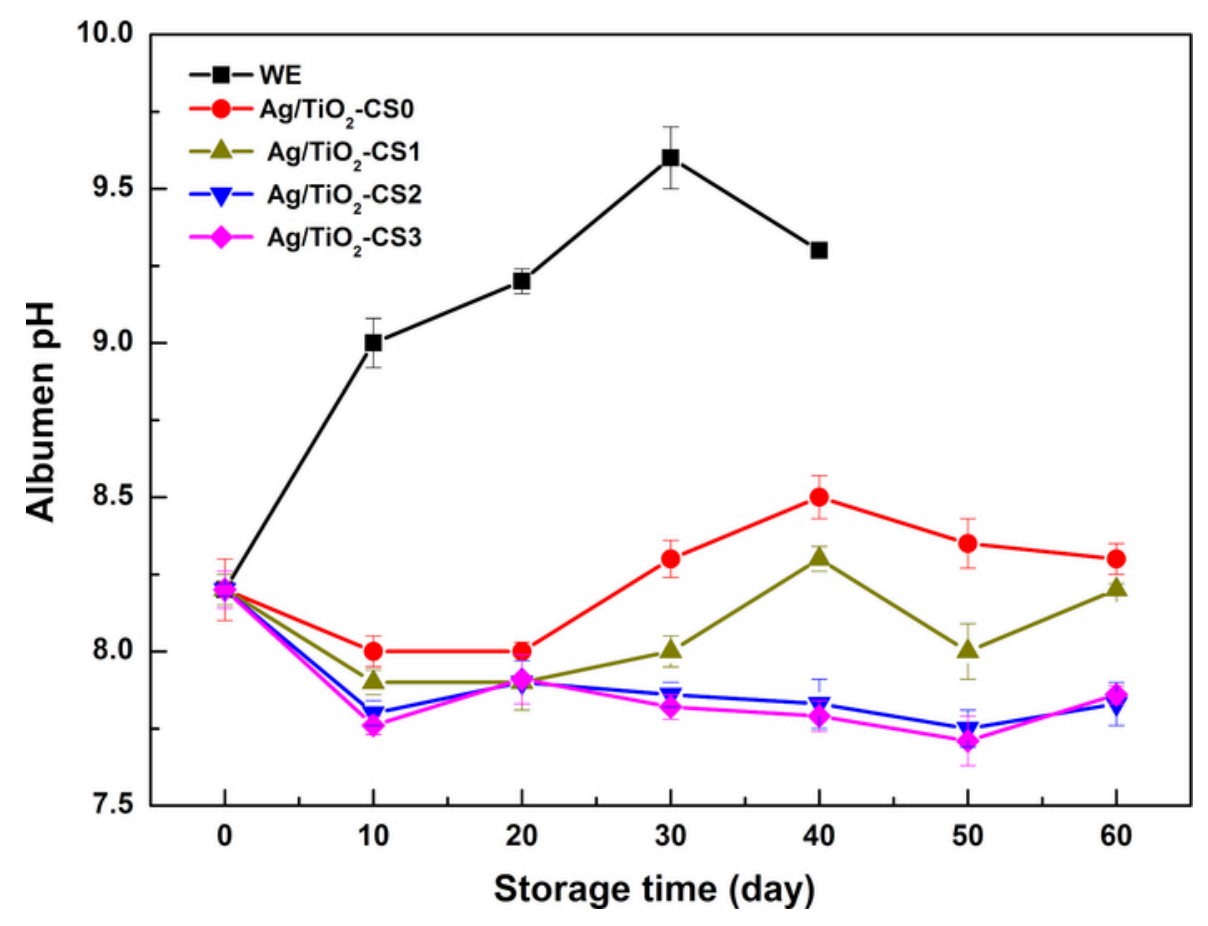

Figure 3: Changes in albumen pH of different eggs during storage time. Please click here to view a larger version of this figure. 


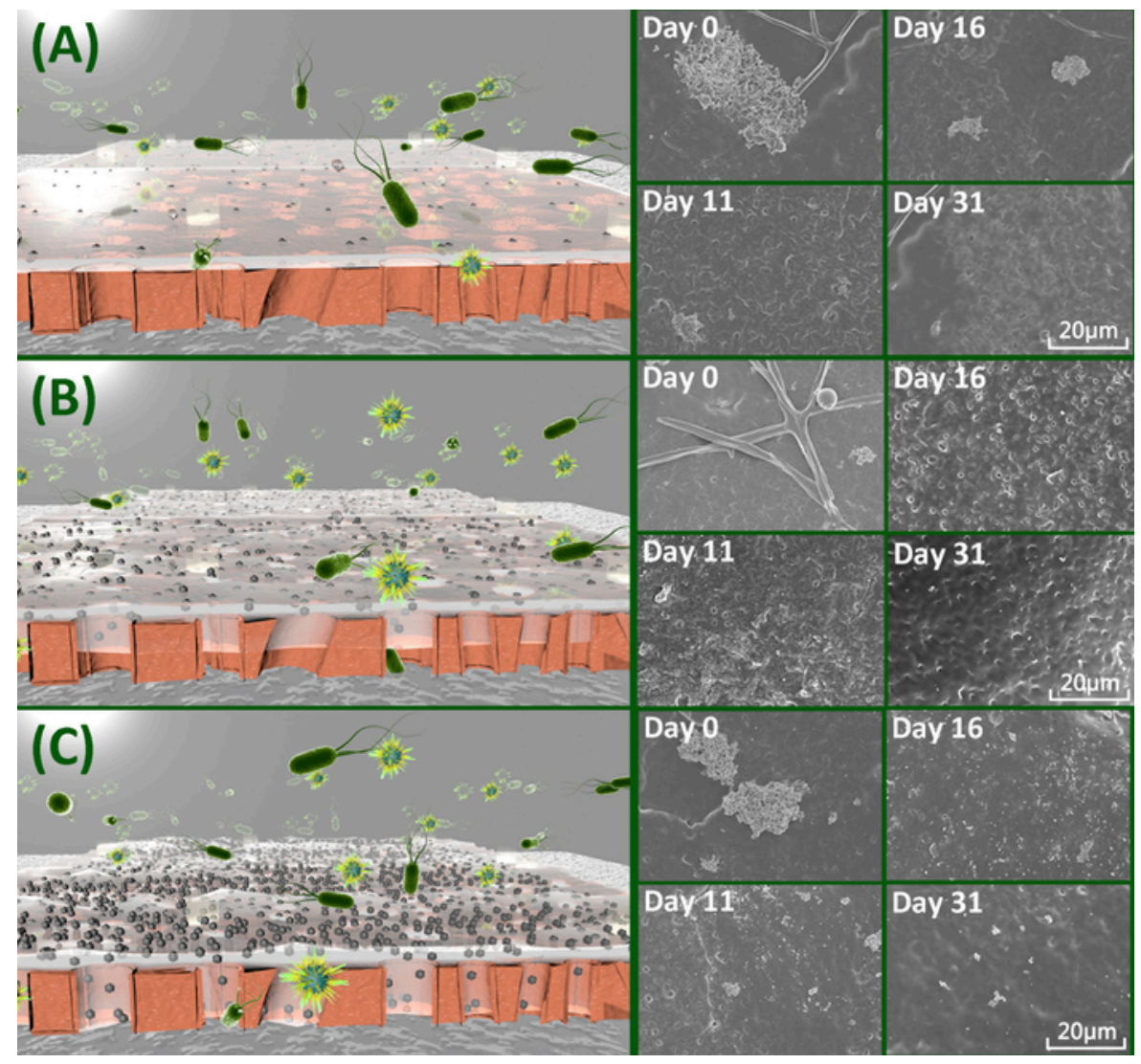

Figure 4: SEM images of Ag/TiO $2-C S$ coated eggshell surfaces at day 0, 11, 16 and 31. (A) Ag/TiO2-CS1; (B) $\mathrm{Ag} / \mathrm{TiO}_{2}-$ CS2; (C) $\mathrm{Ag} / \mathrm{TiO}_{2}-\mathrm{CS} 3$. Please click here to view a larger version of this figure.

\section{Discussion}

Issues of egg protein quality preservation could be relieved by chitosan coating, which has been proven to be an effective way to extend the egg shelf life. The use of a single chitosan coating, however, creates several problems such as instability, limiting the preservation period and the actual application of chitosan-based coatings. Notably, doping specific antibacterial nanoparticles into chitosan has been proposed to extend the shelf life further. In this study, $\mathrm{Ag} / \mathrm{TiO}_{2}$ particles are successfully synthesized and doped into a chitosan coating, which could extend the preservation period to at least 30 days.

SEM images are used to analyze the structure and morphology of the $\mathrm{Ag} / \mathrm{TiO}_{2}$ particles, as well as the morphology of the coated eggshells. The preservation performances of composite coatings are evaluated by the weight loss, Haugh unit, albumen $\mathrm{pH}$ and eggshell morphologies of the samples. Adoption of $\mathrm{Ag} / \mathrm{TiO}_{2}$ composites contributes to a synergistic effect to chitosan, which could prolong the preservation period further. 
The particle sizes of $\mathrm{Ag} / \mathrm{TiO}_{2}$ composites are in the range of 100-300 nm (controlled by the synthesis condition), which could block the pores on the top of eggshell and enhance the preservation performance. However, excess $\mathrm{Ag} / \mathrm{TiO}_{2}$ particles would destroy the layered structure of the chitosan coating, resulting in a lower preservation capacity.

At present, the performances of chitosan coating in this study, however, are limited by the existing particle species and concentrations, which requires optimization in future studies.

The methods in this study demonstrates novel coating materials, which could be mingled by specific nanoparticles into the coating precursor, to achieve combinative effects of nanoparticle and the precursor, as well as to prepare novel multifunctional coatings in the field of food preservation.

\section{Disclosures}

The authors have nothing to disclose.

\section{Acknowledgments}

This work was supported by the Guangxi Key Laboratory of New Energy and Building Energy Saving Foundation (No. 19-J-21-17, 19-J-21-30), Guangxi Universities Scientific Research Project (2020KY06029), and Wuhan University of Technology-Tibet University Joint Innovation Fund (LZJ2020003).

\section{References}

1. Kuroli, S., Kanoo, T., Itoh, H., Ohkawa, Y. Nondestructive measurement of yolk viscosity in lightly heated chicken shelleggs. Journal of Food Engineering. 205, 18-24 (2017).

2. Kostogrys, R.B. et al. Effect of dietary pomegranate seed oil on laying hen performance and physicochemical properties of eggs. Food Chemistry. 221, 1096-1103 (2017).

3. Morsy, M.K., Sharoba, A.M., Khalaf, H.H., El-Tanahy, H.H., Cutter, C.N. Efficacy of antimicrobial pullulanbased coating to improve internal quality and shelf-life of chicken eggs during storage. Journal of Food Science. 80, M1066-M1074 (2015).

4. Damaziak, K. et al. Effect of dietary canthaxanthin and iodine on the production performance and egg quality of laying hens. Journal of Poultry Science. (2018).

5. Sert, D., Aygun, A., Demir, M.K. Effects of ultrasonic treatment and storage temperature on egg quality. Journal of Poultry Science. 90, 869-875 (2011).

6. Yaceer, M., Aday, M.S., Caner, C. Ozone treatment of shell eggs to preserve functional quality and enhance shelf life during storage. Journal of the Science of Food and Agriculture. 96, 2755-2763 (2016).

7. Viswanathan, K., Priyadharshini, M.L.M., Nirmala, K., Raman, M., Raj, G.D. Bactericidal paper trays doped with silver nanoparticles for egg storing applications. Bulletin of Materials Science. 39, 819-826 (2016).

8. Aygun, A., Sert, D. Effects of vacuum packing on eggshell microbial activity and egg quality in table eggs under different storage temperatures. Journal of the Science of Food and Agriculture. 93, 1626-1632 (2013).

9. Ryu, K.N., No, H.K., Prinyawiwatkul, W. Internal quality and shelf life of eggs coated with oils from different sources. Journal of Food Science. 76, S325-S329 (2011).

10. Figueiredo, T.C. et al. Effects of packaging, mineral oil coating, and storage time on biogenic amine levels and 
re

internal quality of eggs. Journal of Poultry Science. 93, 3171-3178 (2014).

11. Caner, C., Ydceer, M. Efficacy of various protein-based coating on enhancing the shelf life of fresh eggs during storage. Journal of Poultry Science. 94, 1665-1677 (2015).

12. Xu, D., Wang, J., Ken, D., Wu, X.Y. Effects of chitosan coating structure and changes during storage on their egg preservation performance. Coatings. 8, 317 (2018).

13. Kopacic, S., Bauer, W., Walzl, A., Leitner, E., Zankel, A. Alginate and chitosan as a functional barrier for paperbased packaging materials. Coatings. 8, 235 (2018).

14. Sagnelli, D. et al. Cross-linked amylose bio-plastic:A transgenic-based compostable plastic alternative. International Journal of Molecular Sciences. 18, 2075 (2017).

15. Megan, T., Robert, C.P., Ivan, P.P., Clara, P. Nanostructured titanium dioxide coatings prepared by aerosol assisted chemical vapour deposition (AACVD). Journal of Phothchemistry and Photobiology AChemistry. 400, 112727 (2020).

Copyright $\odot 2021$ JoVE Creative Commons Attribution-NonCommercial-NoDerivs 3.0 Unsorted

jove.com

July $2021 \cdot 173 \cdot$ e61850 Page 11 of 11 